\title{
Effect of genistein and oestradiol on the adrenal cortex of the ovariectomised adult female albino rats
}

\author{
H.D. Yassa', N.M. Safwat ${ }^{2}$, R.M. Ahmed ${ }^{1}$, M.Z. Fathy ${ }^{3}$, H.L. Metry ${ }^{4}$ \\ ${ }^{1}$ Department of Anatomy and Embryology, Faculty of Medicine, Beni-Suef University, Beni-Suef, Egypt \\ ${ }^{2}$ Department of Pathology, Faculty of Veterinary Medicine, Beni-Suef University, Beni-Suef, Egypt \\ ${ }^{3}$ Department of Surgery, Faculty of Veterinary Medicine, Beni-Suef University, Beni-Suef, Egypt \\ ${ }^{4}$ Department of Anatomy and Embryology, Faculty of Medicine, Cairo University, Cairo, Egypt
}

[Received: 3 April 2020; Accepted: 3 May 2020]

Background: Genistein, a naturally occurring soy isoflavone, attracts interest as an effective and safe alternative to hormone replacement therapy for menopausal problems. The aim of the current study was to compare between the effect of genistein and oestradiol on the adrenal cortex of the ovariectomised adult female albino rats.

Materials and methods: Twenty rats were used in the current study and divided into four groups, 5 rats in each group; group 1 (control non-ovariectomised), group 2 (ovariectomised), group 3 (ovariectomised + genistein) and group 4 (ovariectomised + oestradiol). The rats were sacrificed after 4 weeks. Both adrenal glands were removed for light microscope using haematoxylin and eosin stain, ultrastructural study and immunohistochemical examination using proliferating cell nuclear antigen, caspase-3, and oestrogen receptor- $\beta$.

Results: Ovariectomised rats showed signs of degeneration in all zones of adrenal cortex. On the other hand, treatment with genistein showed restoration of the adrenal cortex with less proliferative effect than oestradiol.

Conclusions: So, genistein can be used as effective therapy to decrease the symptoms of menopause without fear of cancer development. (Folia Morphol 2021; 80, 2: 380-391)

Key words: adrenal, menopause, genistein, oestradiol, rat

\section{INTRODUCTION}

The adrenal glands are paired organs lying near the superior poles of both kidneys. They are embedded in the perirenal adipose tissue and their weight and size vary with the age and physiological conditions [20]. Each gland has two distinct components: a yellowish peripheral cortex ( $80 \%$ to $90 \%$ of the gland) and a reddish brown central medulla [6, 32]. The adrenal cortex is uniquely formed of three major layers organised into concentric zones. The cells of the different zones are generally distinguished by their characteristic cellular arrangement, their ultrastructure as well as their position within the gland. The three zones of the adrenal cortex are the outermost zona glomerulosa (ZG), the middle zona fasciculata (ZF) and the innermost zona reticularis (ZR). These zones are named according to

Address for correspondence: Dr. R.M. Ahmed, Department of Anatomy and Embryology, Faculty of Medicine, Beni-Suef University, Beni-Suef, Egypt, tel: 002-01226655590, e-mail: rowayda_g@yahoo.com

This article is available in open access under Creative Common Attribution-Non-Commercial-No Derivatives 4.0 International (CC BY-NC-ND 4.0) license, allowing to download articles and share them with others as long as they credit the authors and the publisher, but without permission to change them in any way or use them commercially. 
the arrangement of their secretory cells. In human, the limits of these cortical zones are usually not sharply defined [8]. The adrenal cortical hormones play vital roles in different physiological processes, including: fluid and electrolyte balance, cardiovascular homeostasis, carbohydrate, lipid and protein metabolism, immune and inflammatory reactions, reproductive function and sexual development [10].

Menopause is the period in a woman's life when hormonal alterations cause menstruation to stop permanently and may be followed by psychological and physical symptoms. This is due to ovarian failure and oestrogen deficiency which will influence the quality of life. Thus, although menopause appears to be a natural process, it is a period that must be followed and treated. The menopause experiences vary greatly from one female to another [22]. Menopause can occur spontaneously on average around 51 years of age or may be induced by medical intervention (surgery, pelvic radiation therapy or chemotherapy) [18]. It has been reported that bilateral ovariectomy can result in a decrease in the adrenal cortical activity, and oestradiol is used for treatment of this condition [25]. Gaete et al. [9] reported that hormonal therapy with oestrogen was related to the induction of proliferation in the uterus and mammary gland cells, increasing the hazard of cancer development. To prevent these adverse effects, isoflavones are being investigated as alternatives to hormone replacement therapy for menopausal women [19].

Isoflavones are a type of isoflavonoids, which act as phyto-oestrogens in mammals. Genistein, a phyto-oestrogen that belongs to isoflavones, is structurally similar to $17 \beta$-oestradiol, and selective oestrogen receptor modulator. On that account, there has been intense interest in the isoflavones as substitutes for oestrogen for postmenopausal women and as preventive therapy for premenopausal women [19].

\section{MATERIALS AND METHODS}

\section{Animals and experimental protocols}

Twenty adult female albino rats (Sprague-Dawley) weighing 180-200 $\mathrm{g}$ were used in the present work. Rats were provided by Faculty of Veterinary Medicine, Beni-Suef University Animal House and bred in specific pathogen free condition. Rats were housed and maintained in an air-conditioned animal house under standard laboratory and environmental conditions, and were subjected to a 12:12 hours daylight/darkness and allowed free access to food and water. Before carrying out the drug administration, rats were acclimatised in the laboratory for 2 weeks. All the ethical protocols and guidelines for animal handling and treatment were followed and supervised by the animal facilities, Faculty of Veterinary Medicine, Beni-Suef University in compliance with the national standards published in the Guide for the Care and Use of Laboratory Animals.

Rats were divided into four groups; 5 rats each; group 1 - the control group received standard diet only; group 2 - the ovariectomised group (OVX), rats were subjected to ovariectomy operation; group 3 - ovariectomised and treated with genistein group (OVX + genistein); group 4 - ovariectomised and treated with oestradiol group (OVX + oestradiol).

\section{Ovariectomy operation}

Rats were anaesthetised with intraperitoneal injection of ketamine (15 mg/kg body weight). The lower abdomen of the rats was shaved and incised to identify the Fallopian tubes and ovaries. The Fallopian tubes below the ovaries were tied using absorbable vicryl sutures. Then, the ovaries were removed [26].

\section{Drugs}

Genistein: was obtained from Sigma Chemical Company (St. Louis, Missouri, USA). Each 100 mg of genistein was dissolved in $10 \mathrm{~mL}$ distilled water $(10 \mathrm{mg} / \mathrm{mL}$ ) and given orally by gastric tube. The dose was adjusted on the basis of a previous work [31].

Oestradiol: Cyclo-Progynova (oestradiol valerate 2 mg, Bayer Weimar Pharma, AG, Germany), 1 mg/kg/ /day, orally [29].

Drugs were daily ingested by gastric intubation and by the end of application; the gavage tube was left for seconds to avoid regurgitation and to assure supplying the calculated dose completely. All the medications were supplied at a fixed time for the whole period of the experiment.

By the end of the experimental period after 4 weeks, rats were sacrificed by $\mathrm{CO}_{2}$ narcosis. Both adrenal glands of each rat were collected and used for the following methods. One was used for haematoxylin and eosin (H\&E) stain and immunohistochemistry study. The other gland was fixed in glutaraldehyde solution for electron microscopic examination.

\section{Haematoxylin and eosin [7]}

Specimens were fixed in $10 \%$ neutral buffered formalin for $48 \mathrm{~h}$ and were processed to prepare $5 \mu \mathrm{m}$ thick paraffin sections. 


\section{Immunohistochemical stains using}

Proliferating cell nuclear antigen (PCNA) [24]: using PCNA antibody (Clone PC-10). It is a mouse anti-rat monoclonal antibody (Santa Cruz Biotechnology, catalogue number sc-56). It was supplied as $(7.0 \mathrm{~mL})$ of antibody $(200 \mu \mathrm{g} / \mathrm{mL})$ prediluted 1:2000 using phosphate buffered saline (PBS) based antibody diluent, $\mathrm{PH}: 7.4$ to reduce background and unspecific staining. It was stored at $2-8^{\circ} \mathrm{C}$. No special pretreatment was required for immunohistochemical staining of formalin-fixed tissues

Caspase-3 [2]: using caspase-3 (CPP 32) Ab-4. It is a rabbit polyclonal antibody (Lab Vision Corporation Laboratories, USA, RB-1197-R7). It was supplied as prediluted ready-to-use antibody for staining formalin fixed paraffin-embedded tissues. It was stored at $2-8^{\circ} \mathrm{C}$.

Oestrogen receptors (ER- $\beta$ ) [3]: it is a rabbit polyclonal antibody; catalogue number RB-10658-R7 (ready to use for immunohistochemical staining). This antibody labels oestrogen which is detected in human thymus, spleen, ovary and testis and in rat ovary and prostate. It reacts in human and rat and is characterised by nuclear cellular localisation. It was supplied as antibody fraction purified from rabbit anti-serum. Prepared as prediluted antibody which is ready to use for staining of formalin-fixed and paraffin embedded tissues. It's stored at $4^{\circ} \mathrm{C}$. When stored at $2-8^{\circ} \mathrm{C}$, this antibody is stable for 24 months. Staining of formalin-fixed tissues requires boiling tissue sections in $10 \mathrm{mM}$ citrate buffer, $\mathrm{pH}$ 6.0 for 10-20 min followed by cooling at room temperature for $20 \mathrm{~min}$.

\section{Electron microscopy [4]}

After dissecting the rats, 5-10 small pieces $1 \times 1 \mathrm{~mm}$ in size were taken from each specimen and then fixed in 5\% cold glutaraldehyde for 24-48 h. Then, the specimens were washed in cacodylate buffer $(\mathrm{pH}$ 7.2) 3-4 times for 20 min every time and post fixed in $1 \%$ osmium tetroxide $\left(\mathrm{O}_{4} \mathrm{~S}_{4}\right)$ for 2 hours. After that, specimens were washed in the same buffer four times. Ascending grades of alcohol (30-50-70-90 and $100 \%$ ) were used dehydrate the sections ( $2 \mathrm{~h}$ each) and then they were embedded in epon-araldite mixture according to the protocol of E.M. unit, Assiut University. Semi thin sections by LKB ultramicrotome in thickness of 0.5-1 micron were prepared from the embedded blocks for orientation of the tissue and photographed by sc30 Olympus camera. Ultrathin section in thickness of 500-700 A were made using
Leica AG ultramicrotome and contrasted in uranyl acetate and lead citrate, as usual. Examination was performed by JEM 100 CXII electron microscope at $80 \mathrm{KV}$ and photographed by CCD digital camera Model XR-41.

\section{Morphometric study}

Measurements of the width of the 3 cortical zones in all groups were performed using image $J$ programme at the Faculty of Medicine, Beni-Suef University.

\section{Statistical analysis}

Analysis of variance (ANOVA) was used to compare between the different groups in morphometric results and followed by post hoc Tukey test. The results were expressed as means \pm standard deviation. The differences were considered statistically significant when $p$-value was $<0.05$.

\section{RESULTS}

\section{Light microscopy with H\&E stain}

The control group showed the normal histological architecture. The adrenal cortex is covered with thin capsule and an outer layer of adipose connective tissue. It consists of three main zones; the first, ZG is a narrow zone just under the capsule formed of columnar cells with vacuolated cytoplasm and rounded vesicular nuclei. The cells are arranged in arched groups (Fig. 1A). The second, ZF is the widest zone formed of polyhedral cells having clear cell membranes, vacuolated cytoplasm with lipid droplets and large rounded nuclei. The cells are arranged in narrow straight cords (fascicles) separated by straight capillaries (Fig. 2A). The last one, ZR is the deepest zone and is formed of polyhedral cells in branching and anastomosing cords separated by blood sinusoids (Fig. 3A).

In the OVX group, most of the cells in ZG are comparable to control with vesicular nuclei and vacuolated cytoplasm. Few cells have hypochromatic or ghost nuclei (Fig. 1B). The nuclei of the affected cells in both ZF and ZR showed different degrees of pathologic lesions, pyknotic with shrunken and darkly stained nuclei, hypochromatic or had ghost figures. The blood capillaries and sinusoids in between the cortical cells were dilated (Figs. 2B, 3B).

In the OVX + genistein group, a marked amelioration of the degenerative effects were seen in 

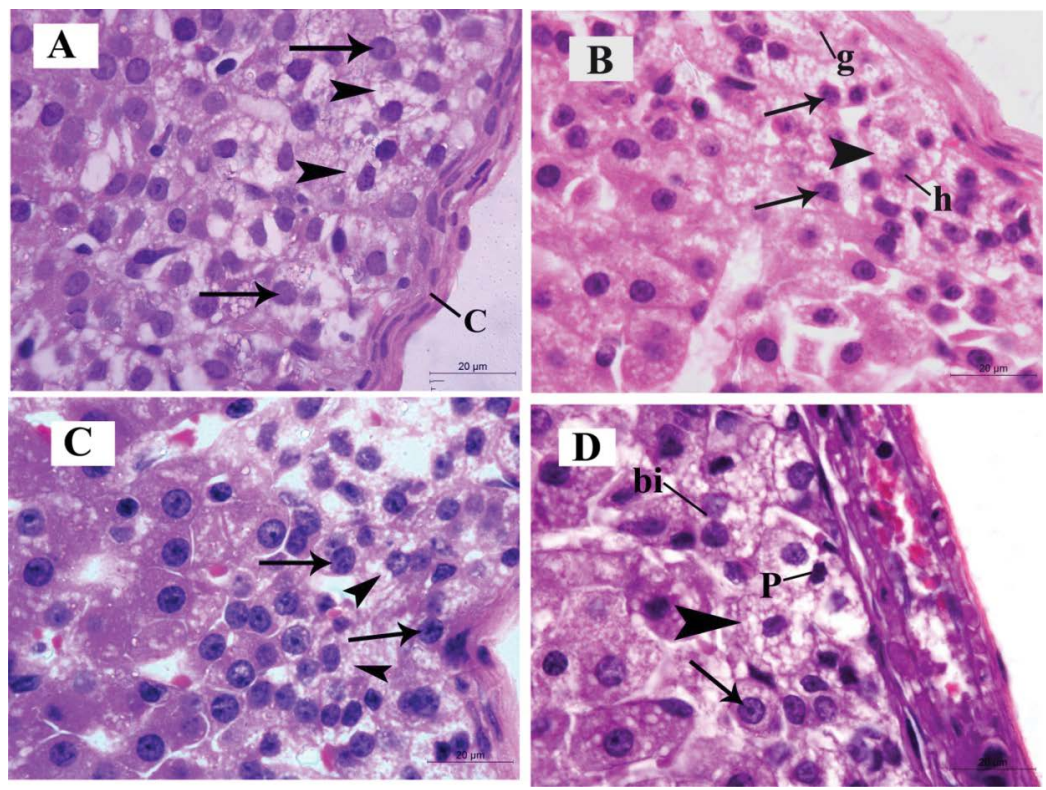

Figure 1. Haematoxylin and eosin-stained sections of zona glomerulosa (ZG) of different studied groups; A. Control group; B. Ovariectomised group (OVX); C. OVX + genistein group; D. OVX + oestradiol group; A. The ZG is covered by capsule (C) and the cells are columnar with vesicular nuclei (arrows) and vacuolated cytoplasm (arrow heads); B. Glomerulosa cells have vesicular nuclei (arrows) and vacuolated cytoplasm (arrow head) and some cells have hypochromatic (h) or ghost (g) nuclei; C. The cells became comparable to control with vesicular nuclei (arrows) and vacuolated cytoplasm (arrow heads); D. Glomerulosa cells have vesicular nuclei (arrow) and vacuolated cytoplasm (arrow head) and some cells are pyknotic (p) and others are binucleated (bi). Scale bar $=20 \mu \mathrm{m}$.
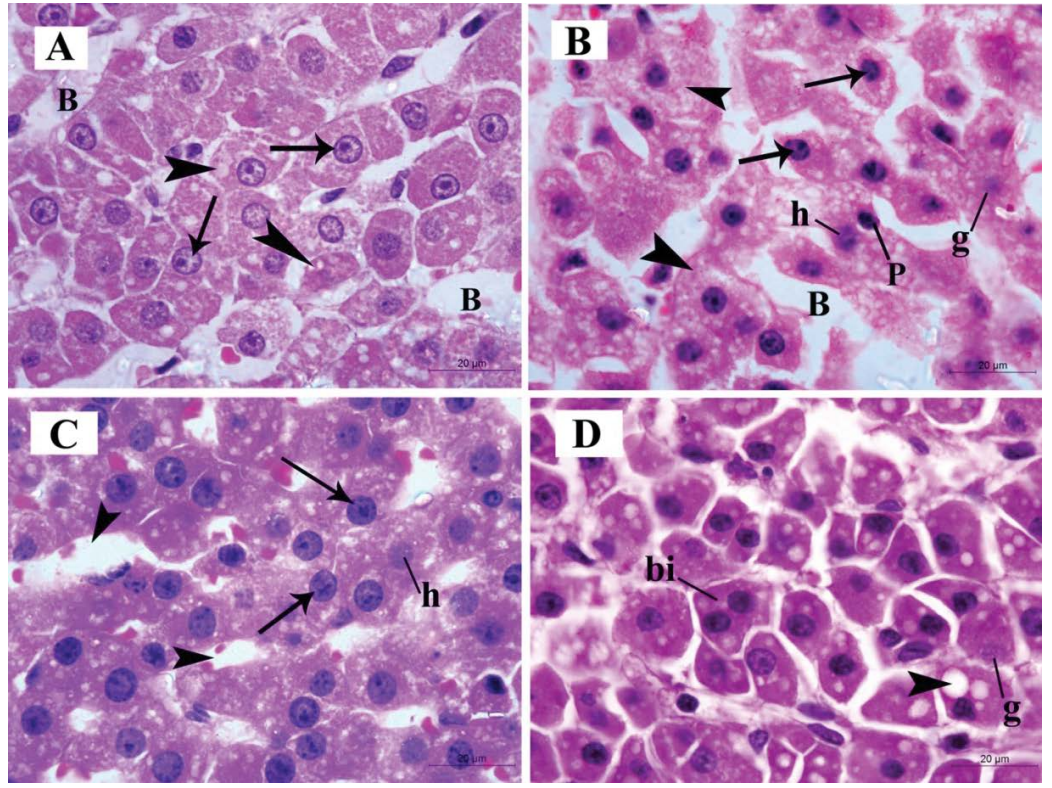

Figure 2. Haematoxylin and eosin-stained sections of zona fasciculata (ZF) of different studied groups; A. Control group; B. Ovariectomised group (OVX); C. OVX + genistein group; D. OVX + oestradiol group; A. The cells in this zone are polyhedral with vesicular nuclei (arrows) and the cytoplasm has few vacuolations (arrow heads). The cells are separated by blood capillaries (B); B. The cells have vesicular nuclei (arrows) and vacuolated cytoplasm (arrow heads) and some cells have pyknotic (p), hypochromatic (h) or ghost (g) nuclei. Fasciculata cells are separated by dilated blood capillaries (B); C. Fasciculata cells became comparable to control with vesicular nuclei (arrows) and few cells have hypochromatic nuclei (h). The blood capillaries between the cells are mildly congested (arrow heads); $\mathbf{D}$. Fasciculata cells are pleomorphic having vacuolated cytoplasm (arrow head). Some cells have ghost figures $(\mathrm{g})$ and others are binucleated (bi). Scale bar $=20 \mu \mathrm{m}$. 




Figure 3. Haematoxylin and eosin-stained sections of zona reticularis (ZR) of different studied groups; A. Control group; B. Ovariectomised group (OVX); C. OVX + genistein group; D. OVX + oestradiol group; A. The cells in this zone are polyhedral with vesicular nuclei (arrows) and the cytoplasm has few vacuolations (arrow heads); B. The cells have vesicular nuclei (arrow) and vacuolated cytoplasm (arrow head) and some cells have hypochromatic $(\mathrm{h})$ or ghost $(\mathrm{g}$ ) nuclei. Reticularis sells are separated by dilated blood sinusoids (S); C. The cells became comparable to control with vesicular nuclei (arrows) and the blood sinusoids between the cells are mildly congested (S); D. Reticularis cells are pleomorphic and binucleated (arrows). They are separated by congested blood sinusoids. Scale bar $=20 \mu \mathrm{m}$.

the majority of rats in the three zones with only few degenerated cells having hypochromatic nuclei and few congested blood capillaries were detected (Figs. $1 \mathrm{C}, 2 \mathrm{C}, 3 \mathrm{C})$.

In the OVX + oestradiol group, there was generalised hyperplasia. The cells were pleomorphic with high mitotic activity. Numerous cells were binucleated and others had pyknotic or ghost nuclei. The blood sinusoids in between the cortical cells were dilated and congested (Figs. 1D, 2D, 3D).

\section{Immunohistochemical staining with PCNA}

Proliferating cell nuclear antigen stained sections of group 1 (control) and group 2 (OVX) revealed negative immunoreaction (Fig. 4A, B). While, group 3 (OVX + genistein) revealed positive immunoreaction (Fig. 4C). Group 4 (OVX + oestradiol) revealed strong positive immunoreaction (Fig. 4D).

\section{Immunohistochemical staining with caspase-3}

Caspase- 3 stained sections of group 1 (control), group 3 (OVX + genistein) and group 4 (OVX + oestradiol) revealed negative immunoreaction (Fig. 5A, C, D), while group 2 (OVX) revealed positive immunoreaction (Fig. 5B).

\section{Immunohistochemical staining with ER- $\beta$}

Oestrogen receptor- $\beta$ stained sections of group 1 (control), group 3 (OVX + genistein) and group 4 (OVX + oestradiol) revealed positive immunoreaction (Fig. 6A, C, D), while group 2 (OVX) revealed negative immunoreaction (Fig. 6B).

\section{Ultrastructural study of the adrenal cortex}

In the control group, ZG cells had rounded or oval nuclei with finely dispersed euchromatin and the nuclear envelope and nuclear pores were easily discerned. The cytoplasm had variable sized numerous lipid globules, medium-sized, rounded or oval mitochondria (Fig. 7A). The fasciculata cells appeared with rounded or oval euchromatic nuclei with clear nuclear envelop rounded mitochondria and variable amount of lipid globules (Fig. 8A). Cells of ZR had vesicular nucleus and abundant cytoplasm which contains few lipid globules and mitochondria (Fig. 9A).

In the OVX group, the adrenal cortical cells showed signs of degeneration. The ZG cells contained vesicular nucleus and the cytoplasm showed few lipid globules which vary in size and electron density. The cytoplasm of the cells also revealed numerous vacu- 


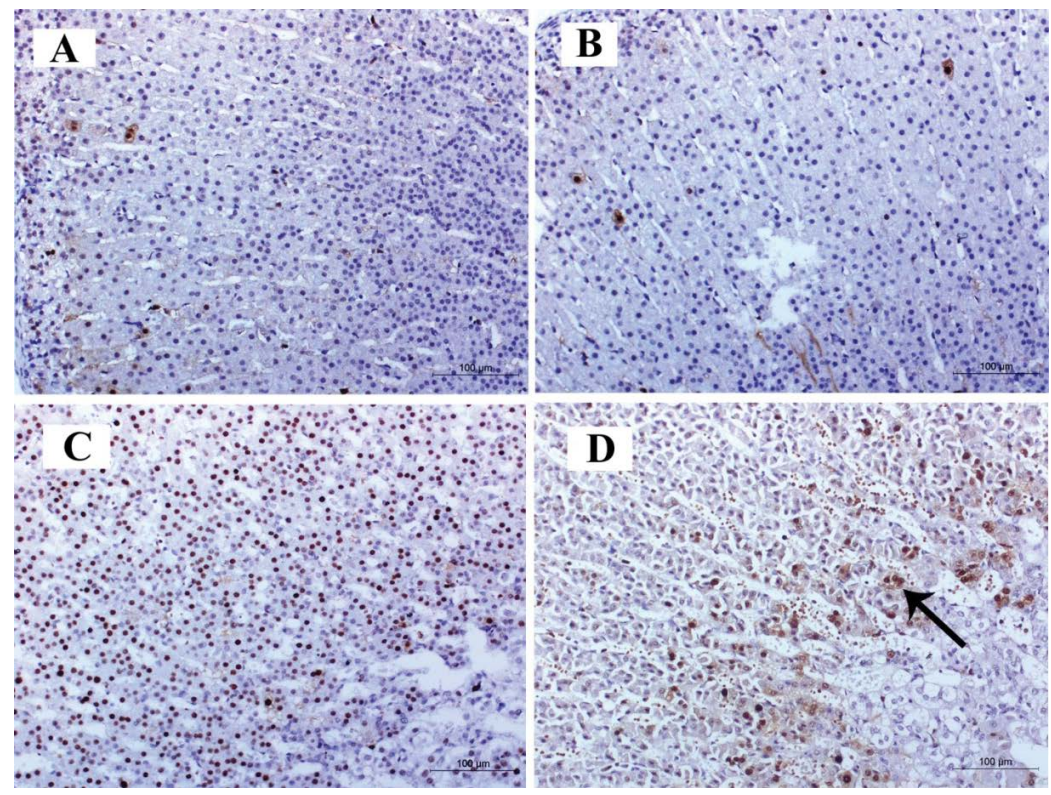

Figure 4. Proliferating cell nuclear antigen-stained sections of different studied groups; A. Control group; B. Ovariectomised group (OVX) are showing negative immunoreaction; C. OVX + genistein group is revealing positive immune reaction; D. OVX + oestradiol group showing strong positive immune reaction (arrow). Scale bar $=100 \mu \mathrm{m}$.

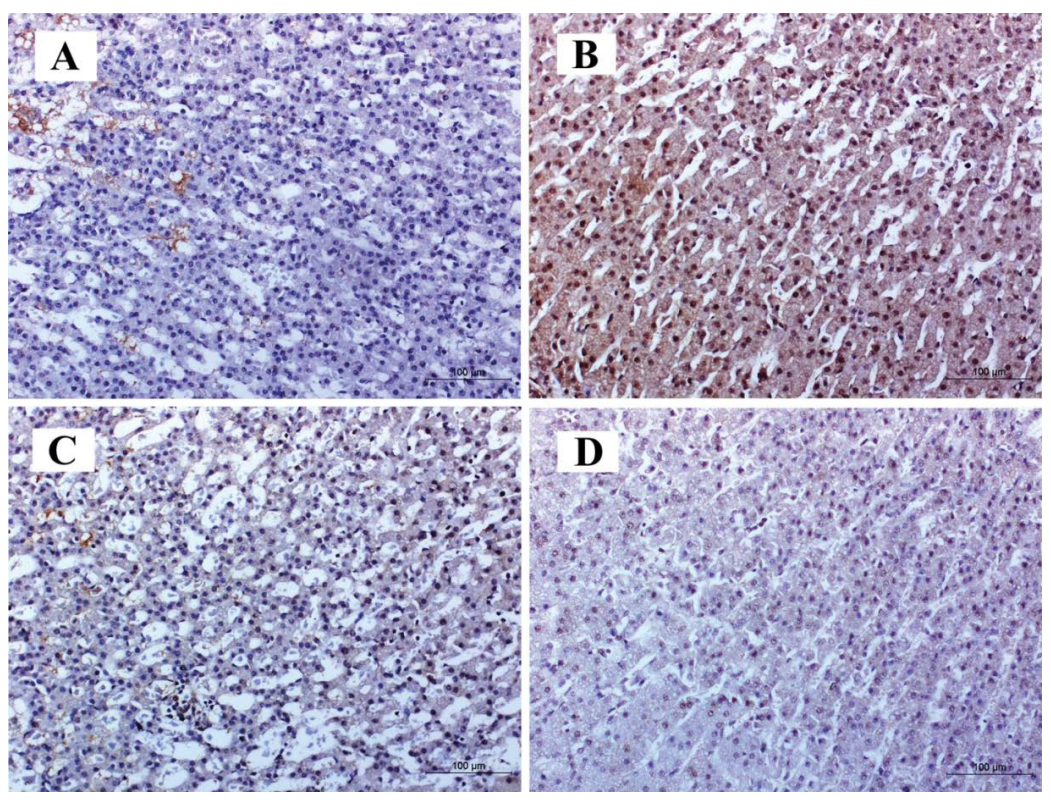

Figure 5. Caspase-3-stained sections of different studied groups; A. Control group; B. Ovariectomised (OVX) group showing strong positive immune reaction; C. OVX + genistein group; D. OVX + oestradiol group showing negative immunoreaction. Scale bar $=100 \mu \mathrm{m}$.

oles and small electron dens lysosomes (Fig. 7B). The ZF cells showed irregular nucleus with thick and irregular nuclear envelope and indistinguishable pores and the cytoplasm contained numerous vacuoles (Fig. 8B). The ZR cells showed irregular nucleus with thick and irregular nuclear envelope and indistinguishable pores and the cytoplasm contained vacuoles and lipofuscin granules (Fig. 9B).
The OVX + genistein group almost regained the normal ultrastructure of cells. The ZG cells showed large amount of electron dens lipid globules, mitochondria, less vacuoles and the nucleus showed normal and regular nuclear membrane, well discerned nuclear pores and finely dispersed euchromatin. Few nuclei became small and condensed (Fig. 7C). The ZF cells showed rounded or oval euchromatic nucleus 


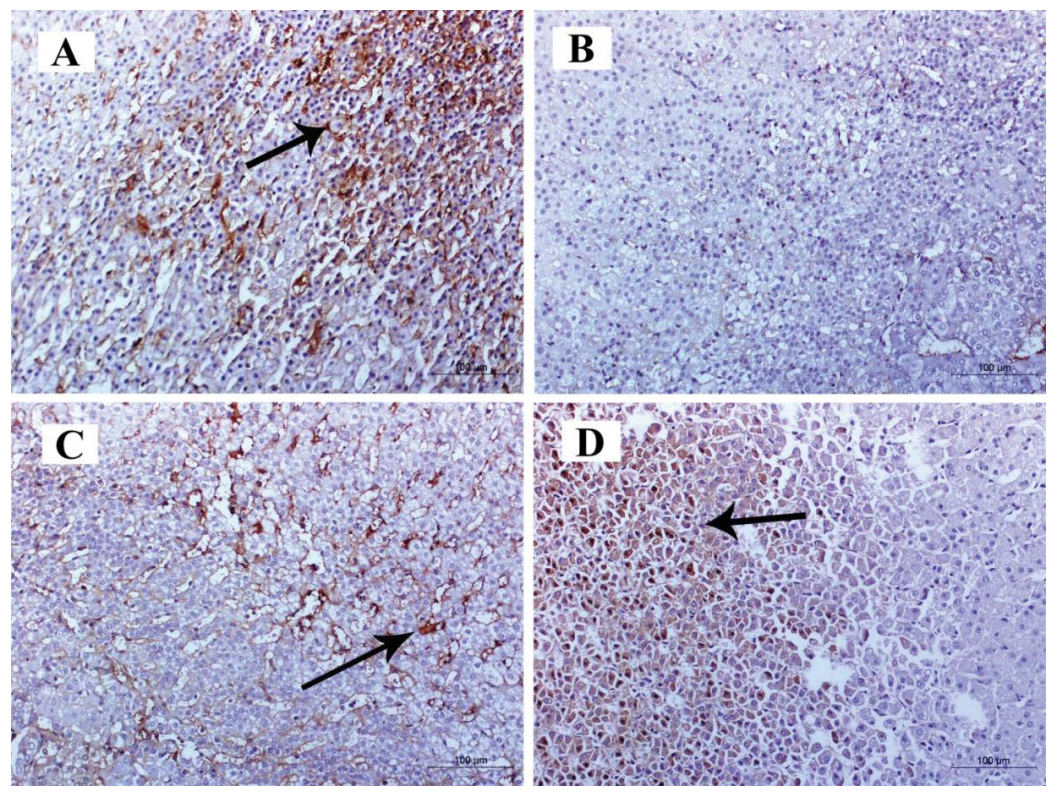

Figure 6. Oestrogen receptor- $\beta$-stained sections of different studied groups; A. Control group; B. Ovariectomised (OVX) group is showing negative immune reaction; C. OVX + genistein group; D. OVX + oestradiol group showing positive immunoreaction (arrows). Scale bar $=100 \mu \mathrm{m}$.
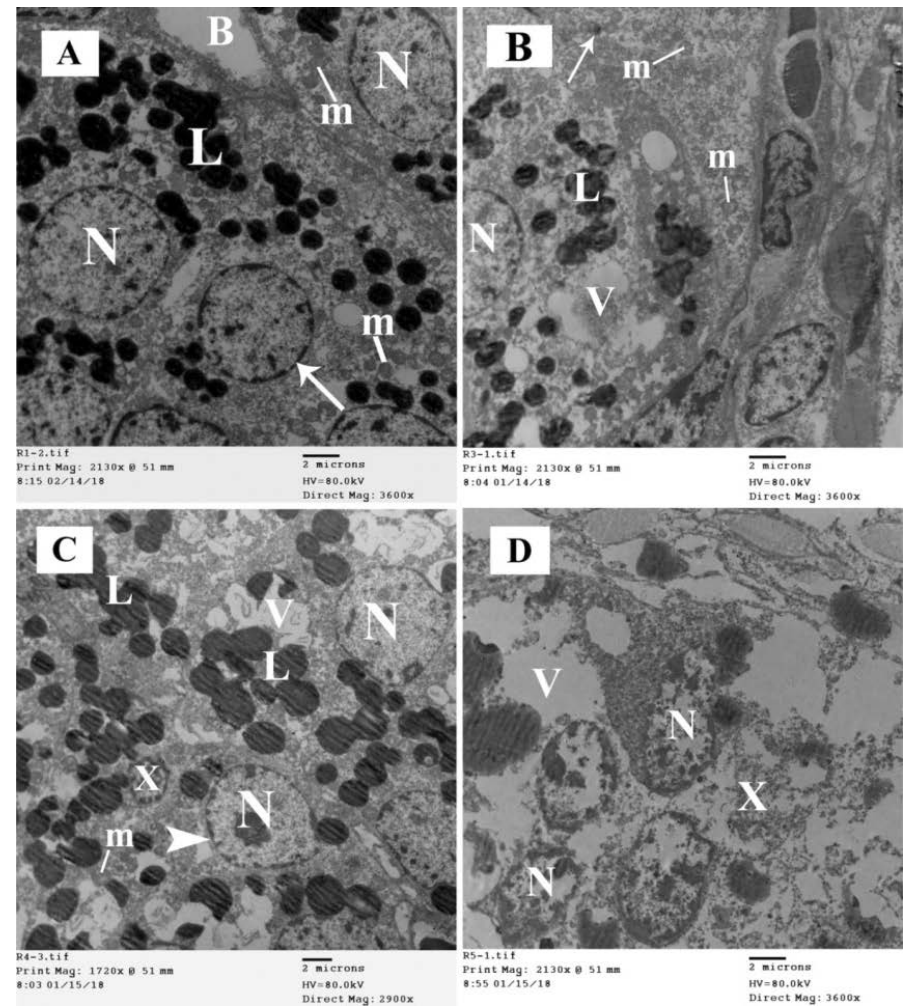

Figure 7. Electron micrographs of the zona glomerulosa (ZG) of the adrenal cortex of different studied groups; A. Control group; B. Ovariectomised (OVX) group; C. OVX + genistein group; D. OVX + oestradiol group; A. Glomerulosa cells have rounded or oval nuclei (N) with finely dispersed euchromatin and the nuclear envelope and nuclear pores are easily discerned (arrow) and the cytoplasm contains spherical or rounded mitochondria $(\mathrm{m})$ and lipid globules (L). The cells are separated by blood capillaries (B); B. The nuclei of the glomerulosa cells are rounded or oval (N) and the cytoplasm contains rounded mitochondria (m), less lipid globules compared to the control group (L), numerous vacuoles (V) and small electron dens lysosomes (arrow); C. The nuclei (N), lipid globules (L) and mitochondria $(\mathrm{m})$ are comparable to control. Few vacuoles $(\mathrm{V})$ are detected and few nuclei became small and condensed (X); D. Glomerulosa cells have condensed nuclei $(\mathrm{N})$ and the cytoplasm contains vacuoles (V) with dispersion of the cell organelles $(\mathrm{X})$. Scale bars: $\mathrm{E}=2 \mu \mathrm{m}$. and the cytoplasm contained variable amount of lipid globules, mitochondria and few lysosomes (Fig. 8C). The cells of ZR appeared of normal structure containing euchromatic nucleus and few lipid globules. Apoptotic cell was seen with loss of its architecture.
Some cells showed condensation of the nucleus chromatin (Fig. 9C).

In the OVX + oestradiol group, the cells forming the ZG had condensed nuclei and the cytoplasm contained large amount of vacuoles with dispersion 

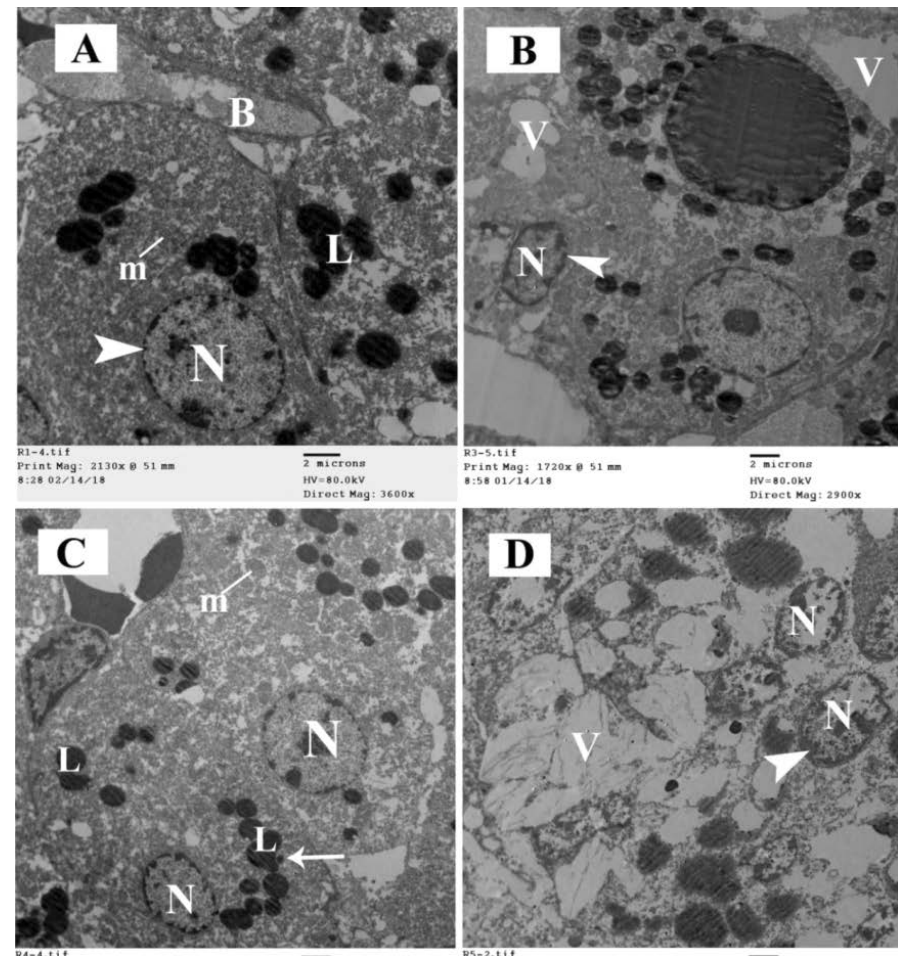

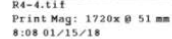
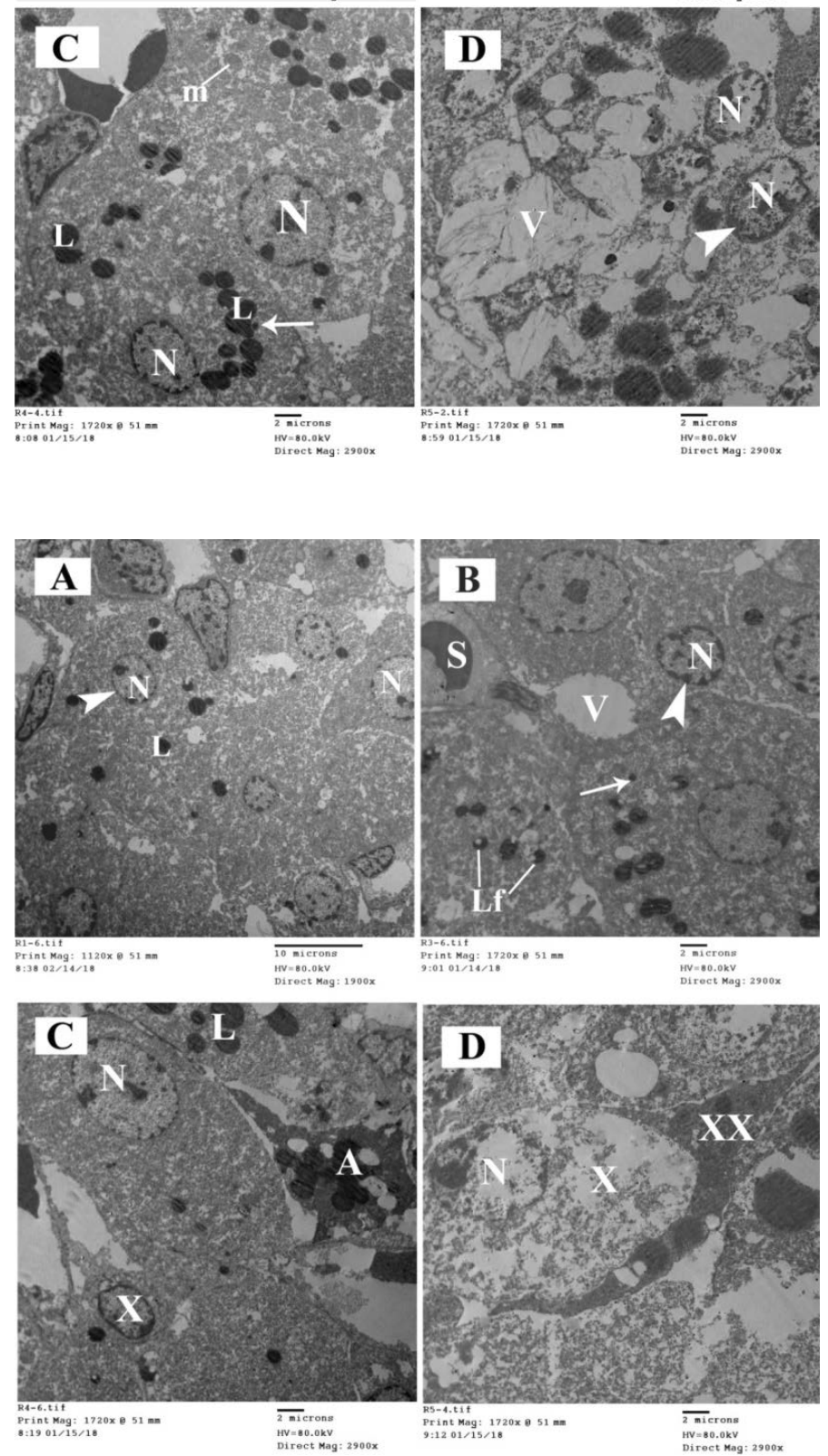

Figure 8. Electron micrographs of the zona fasciculata (ZF) of the adrenal cortex of different studied groups; A. Control group; B. Ovariectomised (OVX) group; C. OVX + genistein group; D. OVX + oestradiol group; A. Fasciculata cells have rounded or oval euchromatic nuclei (N) with regular nuclear envelope and nuclear pores are easily discerned (arrow head) and the cytoplasm contains spherical or rounded mitochondria $(\mathrm{m})$ and lipid globules (L). The cells are separated by blood capillaries (B); B. The cells contain irregular nucleus ( $\mathrm{N}$ (with thick and irregular nuclear envelope and indistinguishable pores (arrow head) and the cytoplasm contains vacuoles (V); C. The cells show rounded or oval euchromatic nuclei (N) and the cytoplasm contains variable amount of lipid globules $(L)$ and rounded mitochondria $(\mathrm{m}) ; \mathbf{D}$. The nuclei of the fasciculata cells (N) are condensed with thick and irregular nuclear envelope and indistinguishable pores (arrow head) and the cytoplasm has large amount vacuoles communicating with each other (V). Scale bars: $E=2 \mu \mathrm{m}$.
Figure 9. Electron micrographs of the zona reticularis (ZR) of the adrenal cortex of different studied groups; A. Control group; B. Ovariectomised (OVX) group; C. OVX + genistein group; D. OVX + oestradiol group; A. The ZR cells have rounded or oval euchromatic nuclei (N) with regular nuclear envelope and nuclear pores are easily discerned (arrow head) and the cytoplasm contains few lipid globules (L); B. Reticularis cells contain irregular nucleus ( $\mathrm{N}$ (with thick and irregular nuclear envelope and indistinguishable pores (arrow head) and the cytoplasm of the cells contains vacuoles (V), lysosomes (arrow) and lipofuscin granules (Lf). The cells are separated by blood sinusoids (S); C. In this zone, the cells contain variable amount of lipid globules (L) and euchromatic nuclei (N). Some cells show condensation of the nucleus chromatin (X) Apoptotic cell $(A)$ is seen with loss of its architecture; D. The cells show dispersion of the cytoplasmic cell organelles (X).The nuclei of the cells $(\mathrm{N})$ are small and electron dens. Apoptotic cell appear electron dens and compressed in between the cells (XX). Scale bars: $A=10 \mu \mathrm{m} ; \mathrm{B}, \mathrm{C}$, $\mathrm{D}=2 \mu \mathrm{m}$. of the cell organelles (Fig. 7D). The ZF cells had large amount of vacuoles communicating with each other and their nuclei were condensed (Fig. 8D).
The ZR cells showed dispersion of the cytoplasmic organelles. The nuclei of the cells were small and electron dens. Also, electron dens apoptotic 
Table 1. Morphometric data of zona glomerulosa thickness in all groups

\begin{tabular}{|c|c|c|c|c|}
\hline \multirow[t]{2}{*}{ Groups } & \multirow[t]{2}{*}{ Mean \pm standard deviation } & \multicolumn{3}{|c|}{ Pairwise comparison between groups } \\
\hline & & This group & Other groups & P-value (significance) \\
\hline Group 1 & $104.45 \pm 12.68$ & 1 & $\begin{array}{l}2 \\
3 \\
4\end{array}$ & $\begin{array}{c}0.0083 \\
0.4344 \\
0.528\end{array}$ \\
\hline Group 2 & $83.80 \pm 3.86$ & 2 & $\begin{array}{l}1 \\
3 \\
4\end{array}$ & $\begin{array}{c}0.0083 \\
0.0144 \\
0.006\end{array}$ \\
\hline Group 3 & $98.53 \pm 9.86$ & 3 & $\begin{array}{l}1 \\
2 \\
4\end{array}$ & $\begin{array}{c}0.4344 \\
0.0144 \\
0.192\end{array}$ \\
\hline Group 4 & $110.45 \pm 15.91$ & 4 & $\begin{array}{l}1 \\
2 \\
3\end{array}$ & $\begin{array}{l}0.528 \\
0.006 \\
0.192\end{array}$ \\
\hline
\end{tabular}

$P<0.05$ is considered significant

Table 2. Morphometric data of zona fasciculata thickness in all groups

\begin{tabular}{|c|c|c|c|c|}
\hline \multirow[t]{2}{*}{ Groups } & \multirow[t]{2}{*}{ Mean \pm standard deviation } & \multicolumn{3}{|c|}{ Pairwise comparison between groups } \\
\hline & & This group & Other groups & P-value (significance) \\
\hline Group 1 & $685.09 \pm 41.52$ & 1 & $\begin{array}{l}2 \\
3 \\
4\end{array}$ & $\begin{array}{l}0.0001 \\
0.0886 \\
0.0001\end{array}$ \\
\hline Group 2 & $371.69 \pm 28.30$ & 2 & $\begin{array}{l}1 \\
3 \\
4\end{array}$ & $\begin{array}{l}0.0001 \\
0.0001 \\
0.0001\end{array}$ \\
\hline Group 3 & $752.15 \pm 65.27$ & 3 & $\begin{array}{l}1 \\
2 \\
4\end{array}$ & $\begin{array}{l}0.0886 \\
0.0001 \\
0.0003\end{array}$ \\
\hline Group 4 & $959.52 \pm 39.61$ & 4 & $\begin{array}{l}1 \\
2 \\
3\end{array}$ & $\begin{array}{l}0.0001 \\
0.0001 \\
0.0003\end{array}$ \\
\hline
\end{tabular}

$\mathrm{P}<0.05$ is considered significant

cells were seen compressed between the cells (Fig. 9D).

\section{Morphometric results}

The ZG thickness was significantly decreased after ovariectomy operation ( $p<0.05$ ) and became comparable to control after treatment with both genistein and oestradiol (Table 1). The thicknesses of ZF (Table 2) as well as ZR (Table 3) were significantly decreased after ovariectomy operation and they were comparable to control after treatment with genistein. In contrast, oestradiol treatment significantly increased ZF and ZR thicknesses compared to group 1, 2 and 3.

\section{DISCUSSION}

In the present study, we examined the effect of ovariectomy on the adult rat adrenal cortex. Additionally, the therapeutic effects of genistein and oestradiol on the adrenal cortex of ovariectomised adult female albino rats were compared. In this experimental study, adult female albino rats aged 3 months old were chosen to be in the reproductive period of life. According to Suckow et al. [27], female rats reach sexual maturity at 2 months of age, their reproductive system is fully functioning and their maximum fertility is reached between 3 and 10 months of age.

In the present study, specimens taken from rats subjected to ovariectomy operation and stained with H\&E showed signs of degeneration in the form of irregular ZF cells and degenerated cortical cells in the form of pyknotic, hypochromatic and ghost nuclei. These findings were in agreement with the findings of Saruhan and Ozdemir [25]. The dilated blood capillaries and sinusoids were also detected. These findings usually accompany the vacuolated cells as reported by Laast et al. [15]. 
Table 3. Morphometric data of zona reticularis thickness in all groups

\begin{tabular}{|c|c|c|c|c|}
\hline \multirow[t]{2}{*}{ Groups } & \multirow[t]{2}{*}{ Mean \pm standard deviation } & \multicolumn{3}{|c|}{ Pairwise comparison between groups } \\
\hline & & This group & Other groups & P-value (significance) \\
\hline Group 1 & $317.98 \pm 24.97$ & 1 & $\begin{array}{l}2 \\
3 \\
4\end{array}$ & $\begin{array}{l}0.0001 \\
0.0510 \\
0.0001\end{array}$ \\
\hline Group 2 & $178.15 \pm 13.74$ & 2 & $\begin{array}{l}1 \\
3 \\
4\end{array}$ & $\begin{array}{l}0.0001 \\
0.0001 \\
0.0001\end{array}$ \\
\hline Group 3 & $366.14 \pm 39.76$ & 3 & $\begin{array}{l}1 \\
2 \\
4\end{array}$ & $\begin{array}{l}0.0510 \\
0.0001 \\
0.0022\end{array}$ \\
\hline Group 4 & $481.50 \pm 42.55$ & 4 & $\begin{array}{l}1 \\
2 \\
3\end{array}$ & $\begin{array}{l}0.0001 \\
0.0001 \\
0.0022\end{array}$ \\
\hline
\end{tabular}

$\mathrm{P}<0.05$ is considered significant

Marked improvement was noticed after treatment with genistein in the degeneration of the cortical cells as they were comparable to control with only few degenerated cells having pyknotic nuclei. On the other hand, treatment with oestradiol showed trophic changes in the form of marked increase in the thickness of the cortical adrenal gland layers with proliferation of the cells compared to ovariectomised rats and rats treated with genistein. This was in agreement with previous findings in the uterus $[5,16]$. Saruhan and Ozdemir [25] determined that ovariectomy resulted in a decrease in the activity of the adrenal cortex. In contrast, they found that oestrogen supplementation caused a significant increase in the activity of the adrenal cortex and medulla. Lo et al. [17] indicated that oestrogens may enhance corticosterone feedback by stimulating corticosterone production at the adrenal gland or by reducing corticosterone metabolism.

In the current study, immunohistochemistry using PCNA revealed moderate proliferation in group 3 , while group 4 showed marked + ve immunoreaction. These findings were in agreement with Marinho et al. [19] who used vascular endothelial growth factor (VEGF) and Ki67 gene expression in the adrenal tissue as proliferative markers and stated that oestrogen induced an increase in the expression of both the VEGF and the Ki67 in rat adrenal glands. On the other hand, the results of the current study showed that treatment with genistein was less effective than with $17 \beta$-oestradiol. They emphasized that genistein has an antagonistic effect, thus supporting the decreased gene expression of VEGF and Ki67 and of proliferation-related genes. VEGF is an important regulated angiogenic molecule and is considered a prognostic factor for various tumours. Thus, these results indicate that genistein may cause less stimulation of VEGF expression than does oestrogen. In fact, some authors have shown that isoflavone may have a weaker effect on tumour induction compared to oestrogen $[12,13,21]$.

In the present study, there was a significant decrease in the thickness of the three adrenal cortical zones in group 2 compared to the control group. These changes may be explained by decreased adrenal cortical activity as reported by Saruhan and Ozdemir [25]. In contrast, non-significant changes were observed in group 3 compared to the control group. This could be explained by the improvement noticed in the adrenal cortical cells after treatment with genistein. Moreover, treatment with oestradiol caused significant increase in the thickness of the adrenal cortical zones compared to group 1, 2 and 3. These findings were going well with the results obtained by Marinho et al. [19] who reported that treatment with soy isoflavone extract induces fewer changes in the thickness of all zones of the adrenal cortex than treatment with oestrogen compared to ovariectomised rats.

In the current work, immunohistochemistry using caspase-3 revealed that + ve reaction appeared only with the group 2 but were -ve in group 3 and 4 . Marinho et al. [19] analysed the expression of caspase-3 gene in order to verify the protective potential of isoflavones. Animals treated with isoflavones showed an expression of caspase-3 more than the 
group treated with oestradiol. This may be related to the proliferative potential of oestradiol, which to some extent can prevent cell death by apoptosis.

Data from many experiments indicate that gonadal hormones have a direct effect on the physiology of the adrenal tissue. ER expression had been demonstrated in the adrenal glands of several species such as rodents [14] and monkeys [11]. In the present study, group 1 exhibited +ve ER- $\beta$ immuno-staining. On the other hand, group 2 showed down-regulation of ER- $\beta$ expression, with -ve ER- $\beta$ immuno-reactivity. After treatment with genistein and oestradiol, many cells exhibited strong + ve ER- $\beta$ immuno-reactivity. Such down regulation of ER- $\beta$ in group 2 probably explains the degenerative changes induced in the cortical cells. Then, the up-regulation of ER- $\beta$ in the groups treated with genistein and oestradiol clearly indicates that ER- $\beta$ expressed by the adrenal cortical cells mediate oestrogen-induced cell proliferation in these cells. These findings postulate that ER- $\beta$ isoform plays an essential role in modifying the effect of oestrogen and thus, further improvement of the adrenal cortex. This was matching with Teng et al. [28] who suggested that ER- $\beta$ isoform plays an important role in modulating the urinary bladder urothelial proliferation.

In the reviewed literature there were no electron microscopic studies observing the ultrastructure of the adrenal cortex in OVX rats and their treatment with either genistein or oestradiol.

Comparable to L.M. examination, the E.M. examination of the adrenal cortex of group 2 showed marked signs of degeneration. The lipofuscin pigments were the most obvious finding in ZR. These results were in agreement with the demonstration carried by Rebuffat et al. [23] and Almeida et al. [1] who observed these findings in aged rats.

Lipofuscin pigments are common structures found in aged ZF and ZR cells and are frequently observed as a classic marker of ageing. Ward and Reznik-Schuller [30] stated that lipofuscin pigments may have originated from degradation of lipid droplets of epithelial cells. Almeida et al. [1] demonstrated that lipofuscin does not exert any noticeable damaging effect on cells but it is possible that, at a certain moment, this accumulation may interfere with cellular function.

The genistein treated group almost regained the normal ultrastructure. While, the oestradiol treated group showed dispersion of the cytoplasmic orga- nelles and apoptotic cells were detected. Similar data have not been reported in the reviewed literature.

\section{CONCLUSIONS}

It could be concluded that ovariectomy decreases the adrenal gland activity due to decreased oestrogen levels in blood. On the other hand, administration of genistein ameliorates the adrenal gland injury without producing trophic effect. Moreover, oestradiol treatment induces an intense cell proliferation as proved histologically, immunohistochemically and ultrastructurally. So, genistein found naturally in soy may have less effect on cell proliferation and cancer risk than oestradiol.

\section{REFERENCES}

1. Almeida $H$, Magalhães $M C$, Magalhães $M M$. Age-related changes in lipid peroxidation products in rat adrenal gland. Age (Omaha). 1998; 21(3): 119-121, doi: 10.1007/ s11357-998-0018-4, indexed in Pubmed: 23604369.

2. Bancroft JD, Gamble M. Theory and practice of histological techniques. 6 th ed. Churchill Livingstone Elsevier, China 2008: 433-472.

3. Bancroft JD, Cook HC. Immunocytochemistry. In: Manual of Histological Techniques and Diagnostic Applications. 1st ed., Churchill Livingstone, Edinburgh, London, Madrid, Melbourne, New York, Tokyo 1994: 263-325.

4. Bozzola J, Russell L. Electron microscopy principles and techniques for biologists: Jones and Bartlitt publishers 20 park plasa, Boston Mao 1991: 2116.

5. Budhathoki S, Iwasaki M, Sawada N, et al. Soy food and isoflavone intake and endometrial cancer risk: the Japan Public Health Center-based prospective study. BJOG. 2015; 122(3): 304-311, doi: 10.1111/1471-0528.12853, indexed in Pubmed: 24941880.

6. Chang SP, Mullins JJ, Morley SD, et al. Transition from organogenesis to stem cell maintenance in the mouse adrenal cortex. Organogenesis. 2011; 7(4): 267-280, doi: 10.4161/org.7.4.18060, indexed in Pubmed: 22198434.

7. Drury R, Wallington E. Carleton's Histological techniques. 5th ed. Oxford 1980: 183-185.

8. Eroschenko VP. DiFiore's atlas of histology with functional correlations. 12th ed. Lippincott Williams and Wilkins, Philadelphia 2013: 402-407.

9. Gaete L, Tchernitchin AN, Bustamante R, et al. Daidzein-estrogen interaction in the rat uterus and its effect on human breast cancer cell growth. J Med Food. 2012; 15(12): 1081-1090, doi: 10.1089/jmf.2011.0322, indexed in Pubmed: 23216111.

10. Hart KA, Barton MH. Adrenocortical insufficiency in horses and foals. Vet Clin North Am Equine Pract. 2011; 27(1): 19-34, doi: 10.1016/j.cveq.2010.12.005, indexed in Pubmed: 21392651.

11. Hirst JJ, West NB, Brenner RM, et al. Steroid hormone receptors in the adrenal glands of fetal and adult rhesus monkeys. J Clin Endocrinol Metab. 1992; 75(1): 308-314, 
doi: 10.1210/jcem.75.1.1619023, indexed in Pubmed: 1619023.

12. Hyder SM, Huang JC, Nawaz Z, et al. Regulation of vascular endothelial growth factor expression by estrogens and progestins. Environ Health Perspect. 2000; 108 Suppl 5: 785-790, doi: 10.1289/ehp.00108s5785, indexed in Pubmed: 11035983.

13. Jarzabek K, Koda M, Walentowicz-Sadlecka M, et al. Altered expression of ERs, aromatase, and COX2 connected to estrogen action in type 1 endometrial cancer biology. Tumour Biol. 2013; 34(6): 4007-4016, doi: 10.1007/ s13277-013-0991-9, indexed in Pubmed: 23873111.

14. Kuiper GG, Carlsson B, Grandien K, et al. Comparison of the ligand binding specificity and transcript tissue distribution of estrogen receptors alpha and beta. Endocrinology. 1997; 138(3): 863-870, doi: 10.1210/endo.138.3.4979, indexed in Pubmed: 9048584.

15. Laast VA, Larsen $\mathrm{T}$, Allison N, et al. Distinguishing cystic degeneration from other aging lesions in the adrenal cortex of Sprague-Dawley rats. Toxicol Pathol. 2014; 42(5): 823-829, doi: 10.1177/0192623313502258, indexed in Pubmed: 24970856.

16. Liu J, Yuan F, Gao J, et al. Oral isoflavone supplementation on endometrial thickness: a meta-analysis of randomized placebo-controlled trials. Oncotarget. 2016; 7(14): 17369-17379, doi: 10.18632/oncotarget.7959, indexed in Pubmed: 26967050.

17. Lo MJ, Chang LL, Wang P. Effects of estradiol on corticosterone secretion in ovariectomized rats. J Cell Biochem. 2000; 77(4): 560-568, doi: 10.1002/(sici)10974644(20000615)77:4<560::aid-jcb4>3.0.co;2-d.

18. Manson JE, Bassuk SS. The menopause transition and postmenopausal hormone therapy. In: Fauci AS, Braunwald E, Kasper DL, eds. Harrison's Principles of Internal Medicine, 17th ed. McGrawHill, New York 2008: 2334-2339.

19. Marinho SD, Calió ML, Santos MA, et al. Evaluation of the isoflavones and estrogen effects on the rat adrenal. Gynecol Endocrinol. 2017; 33(10): 811-815, doi: 10.1080/09513590.2017.1318371, indexed in Pubmed: 28454492.

20. Mescher AL. Adrenal Glands in: Junqueira's Basic Histology: Text and Atlas. 13th ed. Mcgraw-Hill Medical, New York 2013: 414-417.

21. Nagata C, Mizoue T, Tanaka K, et al. Soy intake and breast cancer risk: an evaluation based on a systematic review of epidemiologic evidence among the Japanese population. Jpn J Clin Oncol. 2014; 44(3): 282-295, doi: 10.1093/jjco/ hyt203, indexed in Pubmed: 24453272.
22. Parhizkar S, Abdul Latiff L, Parsa A. Effect of Nigella sativa on reproductive system in experimental menopause rat model. Avicenna J Phytomed. 2016; 6(1): 95-103.

23. Rebuffat $P$, Belloni AS, Rocco $S$, et al. The effects of ageing on the morphology and function of the zonae fasciculata and reticularis of the rat adrenal cortex. Cell Tissue Res. 1992; 270(2): 265-272, doi: 10.1007/BF00328012, indexed in Pubmed: 1333363.

24. Sabry MM, Elkalawy SAE, Abo-Elnour RKD, et al. Histolgical and immunohistochemical study on the effect of stem cell therapy on bleomycin induced pulmonary fibrosis in albino rat. Int J Stem Cells. 2014; 7(1): 33-42, doi: 10.15283/ ijsc.2014.7.1.33, indexed in Pubmed: 24921026.

25. Saruhan BG, Ozdemir N. Effect of ovariectomy and of estrogen treatment on the adrenal gland and body weight in rats. Saudi Med J. 2005; 26(11): 1705-1709.

26. Seko K, Kagami H, Senga K, et al. Effects of ovariectomy and estrogen replacement on rat oral mucosa. Maturitas. 2005; 50(1): 44-51, doi: 10.1016/j.maturitas.2004.03.015, indexed in Pubmed: 15590213.

27. Suckow M, Weisbroth S, Franklin C. The laboratory Rat, 2nd ed. American Colleage of Laboratory Animal Medicine, Academic Press, Toronto 2005.

28. Teng J, Wang ZY, Jarrard DF, et al. Roles of estrogen receptor alpha and beta in modulating urothelial cell proliferation. Endocr Relat Cancer. 2008; 15(1): 351-364, doi: 10.1677/erc.1.01255, indexed in Pubmed: 18310301.

29. Vinicius Carvalho DC, Silveira VÁ, do Prado RF, et al. Effect of estrogen therapy, soy isoflavones, and the combination therapy on the submandibular gland of ovariectomized rats. Pathol Res Pract. 2011; 207(5): 300-305, doi: 10.1016/j.prp.2011.01.002, indexed in Pubmed: 21514062.

30. Ward JM, Reznik-Schüller H. Morphological and histochemical characteristics of pigments in aging F344 rats. Vet Pathol. 1980; 17(6): 678-685, doi: 10.1177/030098588001700604, indexed in Pubmed: 7423828.

31. Yang W, Wang S, Li Li, et al. Genistein reduces hyperglycemia and islet cell loss in a high-dosage manner in rats with alloxan-induced pancreatic damage. Pancreas. 2011; 40(3): 396-402, doi: 10.1097/MPA.0b013e318204e74d, indexed in Pubmed: 21206328.

32. Young B, Woodford P, O'Dowd G. Adrenal Gland. In: Wheater's functional histology: a text and colour atlas. 6 th ed. Elsevier Health Sciences, Philadilphia 2013: 328-331. 